\title{
RESPONSE OF AN INTERMOUNTAIN GROUNDWATER-DEPENDENT ECOSYSTEM TO WATER TABLE DRAWDOWN
}

\author{
Daniel Pritchett ${ }^{1}$ and Sara J. Manning 2,3
}

\begin{abstract}
AвsтRACT.-Groundwater-dependent ecosystems (GDEs) that do not meet the legal definition of wetlands are important for sustaining regional biodiversity, livestock grazing, and outdoor recreation in the Intermountain West. Such GDEs in Owens Valley, California, are also used to produce 11,225 hectare meters (91,000 acre-feet) of water annually from about 100 water wells. We used 21 years of Landsat data and 18 years of field monitoring data to analyze responses of 2 adjacent-meadow GDEs to different groundwater management practices. The northern meadow, which was subject to continuous water table drawdown below the rooting zone of phreatophytic grasses, experienced decline in total live cover from $42.7 \%$ to $30.2 \%$, decline in grass cover from $27.5 \%$ to $14.1 \%$, transition from grass to shrub dominance, and change from groundwater dependence to precipitation dependence. These responses had been predicted by managers in 1976. The southern meadow, which was managed with cycles of water table drawdown and recovery, experienced neither cover decline nor dominance-type conversion and remained groundwater dependent. Variation in depth-to-water table (DTW) explained $83 \%$ of the pooled variance in total live cover in both meadows. Results showed that nonwetland, nonriparian GDEs are vulnerable to water table decline, as are wetland and riparian GDEs. Managing groundwater extraction through imposing one- to several-year cycles of water table drawdown and recovery may avoid further cover decline and type conversion in GDEs already affected by groundwater withdrawals.
\end{abstract}

RESUMEN.-En la región intermontañosa occidental, los ecosistemas dependientes del agua subterránea (de aquí en adelante denominados GDEs por sus siglas en inglés) que no cumplen con la definición legal de humedales son importantes para mantener la biodiversidad regional, el pastoreo de ganado y las actividades recreativas al aire libre. En Owens Valley, California, dichos GDEs también se utilizan para producir anualmente 112.250.000 metros cúbicos de agua de unos 100 pozos de agua. Utilizamos 21 años de datos Landsat y 18 años de datos del monitoreo en campo para analizar las respuestas de 2 prados adyacentes con GDEs a distintas prácticas de manejo de las aguas subterráneas. El prado del norte fue objeto de una reducción continua del nivel freático por debajo de la zona de enraizamiento de freatofitas. Este prado experimentó una disminución total de cobertura viva de un $42.7 \%$ a un $30.2 \%$; la cubierta herbácea también disminuyó de un $27.5 \%$ a un $14.1 \%$; a su vez, exhibió una tendencia que favorecía el dominio de arbustos y no de pastizales, y por último, cambió su dependencia de las aguas subterráneas a una dependencia de la precipitación. Estas respuestas habían sido pronosticadas por expertos en manejo en 1976. El prado del sur, el cual se controló mediante ciclos de reducción y recuperación de los niveles freáticos, no experimentó ni disminución de la cobertura ni ninguna clase de cambio con respecto al tipo de vegetación dominante y mantuvo su dependencia hacia las aguas subterráneas. En ambos prados, la variación en la profundidad de los niveles freáticos explicó el $84 \%$ de la varianza conjunta en el total de cobertura viva. Los resultados mostraron que los GDEs que no son húmedales ni tampoco corresponden a vegetación ribereña son vulnerables al descenso de los niveles freáticos, tal como lo son los GDEs de las zonas ribereñas y de humedales. El control de la extracción de aguas subterráneas a través de la implementación de ciclos de reducción y recuperación de los niveles freáticos que duren de uno a varios años puede evitar que continúe la disminución de la cobertura y que cambie el tipo de vegetación dominante en los GDEs que están siendo afectados por la extracción de agua subterránea.

Not all groundwater-dependent ecosystems (GDEs) are equal in degree of groundwater dependence (Boulton and Hancock 2006); and GDEs such as wetlands and riparian zones, which are protected under the U.S. Clean Water Act, have been the subject of much ecological research (USEPA 2011). Nonwetland, nonriparian GDEs lack federal protection and have been studied less. Notwithstanding, such GDEs may be important for their biodiversity and economic value (City of Los Angeles and County of Inyo 1991a), especially in arid lands of the Intermountain West.

GDEs in Owens Valley, Inyo County, California, are a case in point. They cover over 23,000 ha, and most do not meet the legal wetland

${ }^{1} 401$ East Yaney St., Bishop, CA 93514. E-mail: skypilots@telis.org

${ }^{2}$ Inyo County Water Department, Box 337, Independence, CA 93526

3Present address: Big Pine Paiute Tribe of the Owens Valley Box 700, Big Pine, CA 93513. 
definition (City of Los Angeles and County of Inyo 1991a). Groundwater is not expressed on the surface in these systems, and GDEs may be several kilometers from the nearest surface water. Following the classification of Eamus (2006), we will refer to these systems as Type III GDEs. Owens Valley Type III GDEs sustain a variety of sensitive species including endemics such as Sidalcea covillei (Owens Valley checkerbloom), Calochortus excavatus (Inyo County star-tulip), Astragalus lentiginosus var. piscinensis (Fish Slough milkvetch), and Microtus californicus ssp. vallicola (Owens Valley vole). Type III GDEs support livestock grazing and provide recreational opportunities (City of Los Angeles and County of Inyo 1991a).

Owens Valley Type III GDEs also encompass or adjoin nearly 100 wells, which are used to extract about 11,225 hectare meters $(91,000$ acre-feet) of water annually (Los Angeles Department of Water and Power 2011). Operation of these wells is conducted under the terms of the Inyo County/Los Angeles Long Term Water Agreement (Water Agreement) — a management agreement that allows water to be pumped, provided adverse impacts to GDEs are avoided (City of Los Angeles and County of Inyo 1991a). Management is based on a conceptual model of exploiting the ecological resilience of GDEs by imposing cycles of pumping-induced water table drawdown and recovery (Groeneveld 1992). Pursuant to the Water Agreement, certain sites have been the subject of intensive monitoring of vegetation and groundwater levels.

In this paper, we use 21 years of Landsat and hydrologic data in conjunction with 18 years of field monitoring data to analyze vegetation response along a pumping-induced depth-towater table (DTW) gradient. We chose our study site, which consists of 2 adjacent meadows, because it was dominated by native phreatophytic grasses when the DTW gradient was imposed and monitoring began (City of Los Angeles and County of Inyo 1991b). Changes in the meadows represent a case study in the responses of relatively intact (in regard to dominant species) Type III alkali-meadow GDEs to water table drawdowns of different magnitudes and durations. Our objectives were to document changes in vegetation cover and dominant life form in each meadow and analyze these changes in relation to DTW and precipitation. Results may be useful for GDE management in other arid regions.

\section{STUdy Site}

Owens Valley is a $120-\mathrm{km}$ trough at the western edge of the Great Basin (Fig. 1). The Sierra Nevada forms the valley's western wall and creates a rain shadow. Mean annual precipitation ranges from 127 to $152 \mathrm{~mm}$, and more than three-quarters falls during the cold months, October-March (Hollett et al. 1991). The study site meadows lie at the toe of large, coalesced alluvial fans descending from the Sierran escarpment about $13 \mathrm{~km}$ north of the town of Independence, California. Substrate is a combination of ancient beach, bar, or riverchannel sediments lying between alluvial fan deposits upslope to the west and fluvio-lacustrine deposits downslope to the east (Hollett et al. 1991). Soils are moderately to poorly drained loams (USDA-NRCS 2002), and elevation ranges from approximately $1178 \mathrm{~m}$ at the northwest corner to $1160 \mathrm{~m}$ at the southeast corner. The study site meadows cover about 204 ha and have been open to livestock grazing since Euro-American settlement in the 1860s. Livestock are removed in spring, approximately one month before vegetation data are collected. Analysis of postfire regrowth with grazing excluded (Pritchett and Manning 2009) and analysis of long-term monitoring data in grazing exclosures in both meadows (Inyo County Water Department 2011) suggest that the vegetation patterns and trends identified in our study occur independently of grazing effects.

Ecosystem conditions were first documented by C.H. Lee (1912). He noted the "striking correlation between vegetation and depth to groundwater," and he mapped and described an extensive zone of grass-dominated meadow on the west side of Owens Valley. The meadow zone occurred on alluvial-fan, toe-slope areas where DTW was $2.4 \mathrm{~m}(8 \mathrm{ft})$ or shallower. Upslope, he documented a narrow zone of facultative phreatophytic shrubs, then Mojave Desert shrubland. All but the northwestern edge of our study site falls within Lee's grassdominated meadow zone (Fig. 1).

Lee (1912) also described the annual hydrographic signature of groundwater dependence. He observed in the meadow zone a water table decline of about $1 \mathrm{~m}$ commencing with the beginning of the growing season in spring, followed by rising water tables at the end of the growing season in autumn. Lee attributed 


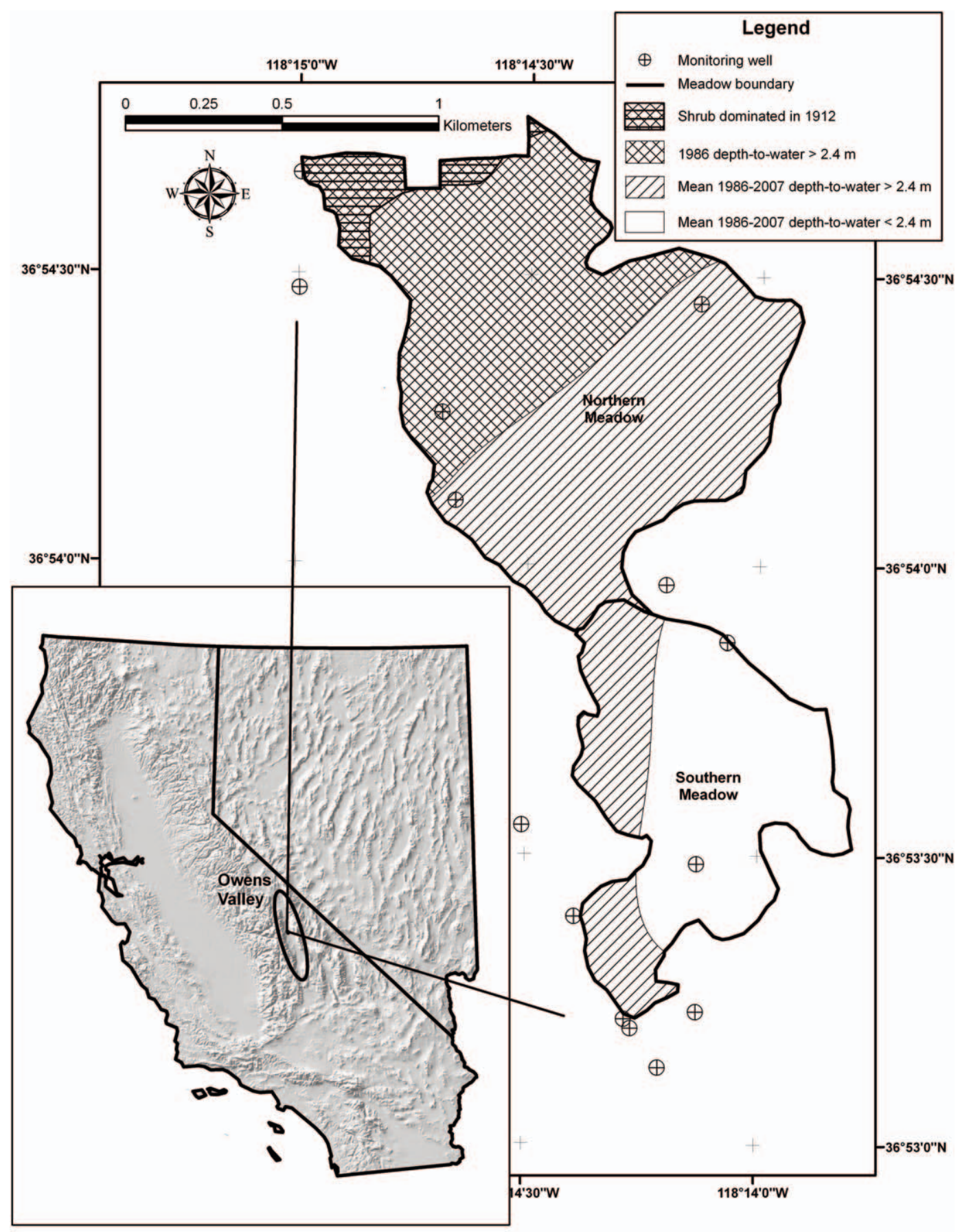

Fig. 1. Study site in central Owens Valley, California, including northern and southern meadow boundaries and monitoring wells used for kriging depth-to-water. Also shown is the 1912 area of shrub dominance and areas with depth-towater $>2.4 \mathrm{~m}$ - the value associated by Lee (1912) with the meadow-shrubland ecotone. Geographic coordinate system: Universal Transverse Mercator zone 11, NAD 27 datum. 
TABLE 1. Mean baseline (1986) cover by species, based on $(n)$ number of transects in northern and southern study site meadows, Owens Valley, California.

\begin{tabular}{|c|c|c|}
\hline \multirow[b]{2}{*}{ Taxon } & \multicolumn{2}{|c|}{ Mean percent cover } \\
\hline & $\begin{array}{c}\text { Northern } \\
\text { meadow } \\
(n=9)\end{array}$ & $\begin{array}{c}\text { Southern } \\
\text { meadow } \\
(n=8)\end{array}$ \\
\hline \multicolumn{3}{|l|}{ Perennial graminoid } \\
\hline Sporobolus airoides & 19.3 & 30.3 \\
\hline Distichlis spicata & 8.2 & 9.0 \\
\hline Juncus balticus & 0.7 & 0.8 \\
\hline Spartina gracilis & 0.0 & 0.1 \\
\hline unknown Carex sp. & 0.6 & 0.0 \\
\hline \multicolumn{3}{|l|}{ Shrub } \\
\hline \multicolumn{3}{|l|}{ Atriplex lentiformis } \\
\hline ssp. torreyi & 5.1 & 3.0 \\
\hline \multicolumn{3}{|l|}{ Ericameria nauseosa } \\
\hline Nesom \& Baird & 3.4 & 2.9 \\
\hline Sarcobatus vermiculatus & 0.1 & 0.3 \\
\hline $\begin{array}{l}\text { Artemisia tridentata } \\
\text { ssp. tridentata }\end{array}$ & 1.8 & 0.0 \\
\hline \multicolumn{3}{|l|}{ Perennial herb } \\
\hline Glycyrrhiza lepidota & 1.3 & 1.6 \\
\hline Nitrophila occidentalis & 0.0 & 0.1 \\
\hline \multicolumn{3}{|l|}{ Annual graminoid } \\
\hline ssp. rubens & 0.1 & 0.0 \\
\hline Cynodon dactylon & 0.2 & 0.0 \\
\hline Hordeum jubatum & 0.1 & 0.0 \\
\hline \multicolumn{3}{|l|}{ Annual herb } \\
\hline unknown annual forb & 0.9 & 1.8 \\
\hline Atriplex phyllostegia & 0.0 & 0.4 \\
\hline Bassia hyssopifolia & 0.1 & 0.0 \\
\hline Descurainia pinnata & 0.3 & 0.0 \\
\hline Descurainia sp. & 0.0 & 0.5 \\
\hline Erodium cicutarium & 0.2 & 0.0 \\
\hline Salsola tragus & 0.1 & 0.0 \\
\hline
\end{tabular}

this regular pattern of within-year water table drawdown and recovery to initiation and cessation of evapotranspiration. His data distinguished this signature of groundwater-dependence from deeper and irregular water table fluctuations upslope under precipitation-dependent shrub vegetation (Lee 1912).

The study site meadows were sampled by the Los Angeles Department of Water and Power in 1986 to characterize species composition and cover (Table 1). Dominant grasses were Sporobolus airoides (alkali sacaton) and Distichlis spicata (saltgrass) (nomenclature follows Baldwin et al. 2002, unless otherwise noted). The most common shrub species were Atriplex lentiformis ssp. torreyi (Nevada saltbush), Ericameria nauseosa (Pall. Ex. Pursh) G.L. Nesom \& Baird (rubber rabbitbrush), and Artemisia tridentata Nutt. ssp. tridentata (basin big sagebrush). Less common species included Glycyrrhiza lepidota (American licorice), Juncus balticus (wire grass), and other herbaceous annual and perennial species (City of Los Angeles and County of Inyo 1991b). Pritchett and Manning (2009) presented a list of species recorded for the entire study site as of 2007. Sporobolus airoides and D. spicata are classified as "facultative" and "facultative wetland," respectively, with regard to wetland indicator status in California. "Facultative" is assigned to species equally likely to occur in wetland and nonwetlands, and "facultative wetland" is assigned to species usually occurring in wetlands. None of the shrubs are regarded as wetland indicators (USDA-NRCS 2011). The maximum effective rooting depths for Owens Valley phreatophytic shrubs and grasses were determined to be $3.7 \mathrm{~m}$ and $2 \mathrm{~m}$, respectively (City of Los Angeles and County of Inyo 1991b).

Groundwater management of the study site meadows differed; however, the different treatments were a product of geography rather than management intention. The northern meadow is located southwest of 2 large pumps which operate continuously. The pumps are exempt from Water Agreement management protocols which would otherwise have required their operation to cease in order to facilitate water table recovery (City of Los Angeles and County of Inyo 1991b). High volumes of pumping during 1987-1989 from many wells in the area (Pritchett and Manning 2009) combined with drought conditions lowered the water table under the northern meadow to over $8 \mathrm{~m}$ below ground surface at rates of up to $110 \mathrm{~cm} \cdot$ year $^{-1}$ (Fig. 2). With diminished pumping and the end of drought conditions, DTW recovered to about $5 \mathrm{~m}$ below ground surface. As a result, mean DTW under the northern meadow has remained well below the rooting zone of phreatophytic grass since 1988. In contrast, mean DTW under the southern meadow declined to only about $3 \mathrm{~m}$ at rates up to $70 \mathrm{~cm} \cdot$ year $^{-1}$. During the1990s, the water table rose to about $2 \mathrm{~m}$; and since 1998, it has fluctuated near the bottom of the grass rooting zone (Fig. 2).

\section{Methods}

Between 1984 and 1987, Los Angeles Department of Water and Power staff used air photos to circumscribe their Owens Valley land 


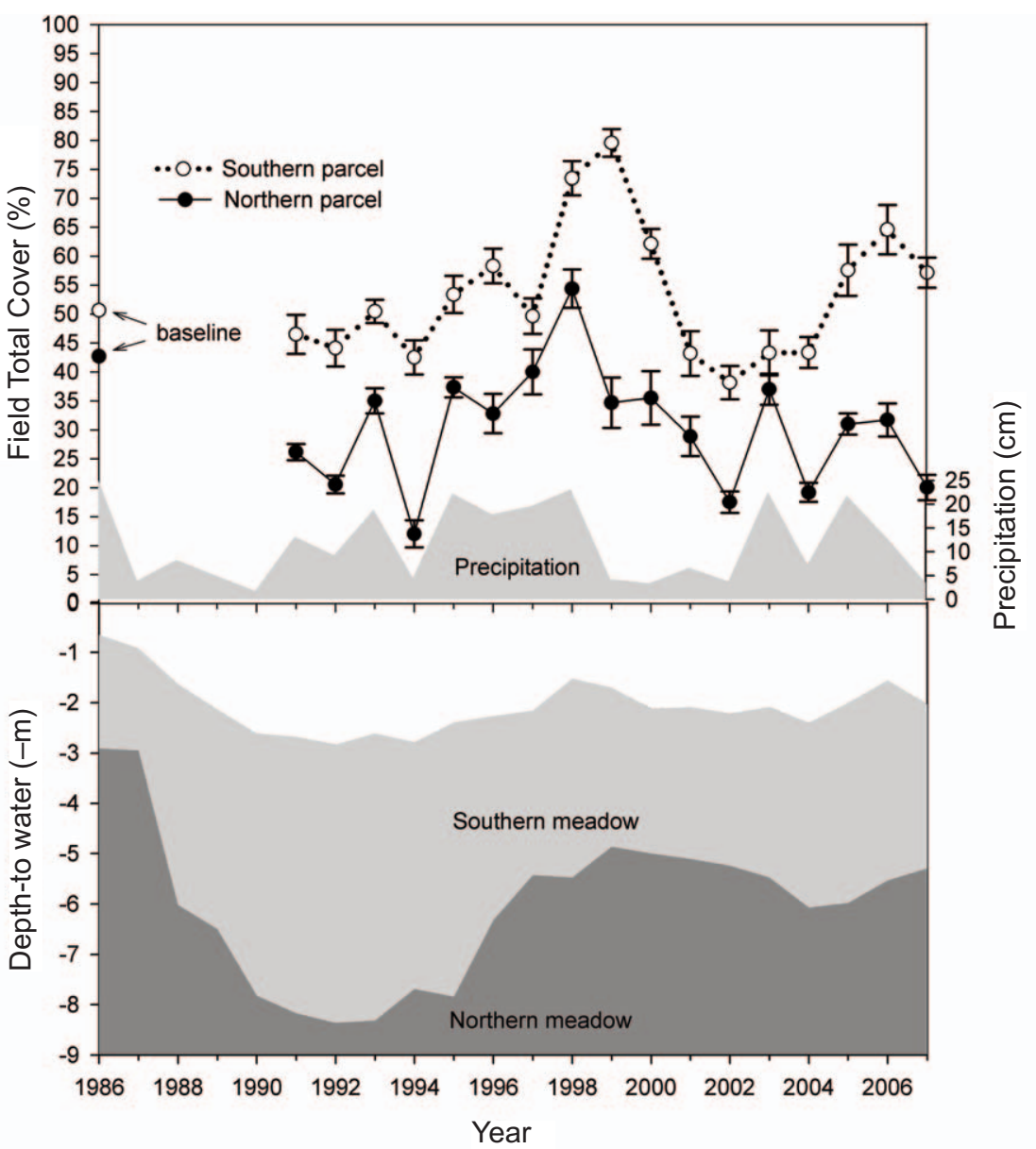

Fig. 2. Annual mean field total cover 1991-2007, 1986 baseline cover, pregrowing season precipitation, and mean depth-to-water for northern and southern study site meadows, Owens Valley, California. Error bars represent standard error.

into units of homogeneous vegetation referred to as "parcels." The 2 study site meadows were defined as separate parcels in this project. Every parcel was sampled for species composition and top-layer canopy cover by running transects, $30.5 \mathrm{~m}$ (100 ft) in length, which were read using the point-intercept method (Bonham 1989). The data and parcel circumscriptions were subsequently accepted in the Water Agreement as management goals and baseline conditions against which pumpinginduced changes would be measured. Although we follow Water Agreement usage and refer to these cover and composition data as baseline data, these data do not document undisturbed conditions. Vegetation in the study site meadows had already been subjected to intermittent periods of pumping-induced hydrologic alteration when baseline data were gathered (City of Los Angeles and County of Inyo 1991a).

Inyo County Water Department implemented the Water Agreement's annual parcel monitoring protocol in 1991 to gather data for comparisons with conditions measured in baseline data. Inyo staff sampled top-level live canopy cover in selected parcels with randomly placed $50-\mathrm{m}$ transects, which were read according to the point-intercept method (City of Los Angeles and County of Inyo 1991b). In both study site meadows, 12-26 transects were placed annually (1991-2007) in mid- to late June (Manning 2006). We refer to data from this sampling as "field cover." The annual monitoring was designed to measure changes in dominant species. The methodology and relatively small number of transects did not 
reliably detect understory, smaller, and less abundant species. For these reasons we restricted response variables in our analyses to total live cover and cover of selected life forms.

Total photosynthetic vegetation cover of both study site meadows was measured annually using linear spectral mixture analysis of Landsat Thematic Mapper data (Elmore et al. 2000). These data are referred to as "SMA cover." Unlike field cover, they do not allow cover to be attributed to particular species or life forms. However, they have the advantage of being available for every year since the year baseline field data were gathered for the 2 study site meadows. Furthermore, Landsat data cover the full spatial extent of both meadows, thus representing a more complete sample than that obtained from the limited number of field transects. We used SMA cover from the period 1986-2006. Because Landsat data were collected in late August or September of each year and a fire burned large sections of both meadows in July 2007 (Pritchett and Manning 2009), we did not include 2007 SMA cover.

\section{DTW and Precipitation Data}

There are 14 groundwater monitoring wells in and adjoining the study site (Fig. 1), and we obtained their spring DTW values for the years 1986-2007 from Inyo County. Spring (ca. 1 April) values are well suited for interyear studies of cover and DTW because they typically represent the annual water table high before initiation of within-year, evapotranspiration-induced drawdowns (Lee 1912). We used the spring DTW data as control points to create grids of kriged DTW estimates for the study area for each year, 1986-2007 (ESRI 2008). Kriging is recommended for interpolation in cases where sample sites are irregularly spaced (Legendre and Legendre 1998) and has been used by the Inyo County Water Department (Harrington and Howard 2000, Harrington 2003) to estimate mean spring DTW under vegetation parcels. We estimated mean DTW under each meadow by overlaying meadow boundaries on each annual grid of kriged DTW estimates and then calculating the mean of all grid cells in each meadow for each year.

We obtained daily precipitation data $(\mathrm{cm})$, 1991-2007, from a Los Angeles Department of Water and Power rain gauge in the town of
Independence, California, about $13 \mathrm{~km}$ to the south of the study site. We used water year precipitation (1 October-30 September) for correlations with SMA cover because SMA cover was gathered at the end of the water year. We used pregrowing season (1 October-30 June) precipitation for correlation with field cover (instead of water year precipitation) to exclude any precipitation which fell after sampling had been completed.

\section{Data Analysis}

Cover Change.-We used transect data to calculate mean field total cover, grass cover (the sum of S. airoides and D. spicata), and shrub cover (all shrub species) for each study site meadow for each year, 1991-2007. Cover of other species was not included in this analysis; hence the sum of shrub cover and grass cover is slightly less than total cover. We regarded baseline means as standards without variance and applied one-sample $t$ tests to test hypotheses that 1991-2007 mean field total, grass, and shrub covers were equal to their respective baseline values (Statsoft 2005). Baseline means were treated as standards without variance because transect locations were not random but had been selected as representative of the meadows (City of Los Angeles and County of Inyo 1991b). This limits their use for statistical inference (Zar 1984). Our use of these data is consistent with use by the Los Angeles Department of Water and Power (2011) and addresses its objections to the use of baseline and subsequent monitoring data (randomly sampled) in 2-sample $t$ tests (Coufal 2001).

DOMINANCE-TYPE CONVERSION.-We divided grass cover by the sum of grass plus shrub cover to compute a grass proportion for each meadow and used results as an indicator of grass dominance. A value of 1 indicates all grass cover and no shrub cover; a value of 0 indicates no grass cover and all shrub cover. We used ordinary least-squares regression to examine the change in grass proportion over time (1991-2007) in each meadow. We computed the Durbin-Watson Statistic to test for the presence of serial correlation in the dependent variables in these regressions (Systat 2006).

Cover-Water RELationships.-Due to the difficulty of normalizing distributions of precipitation and northern meadow DTW values, we used Spearman's R to identify correlations of 


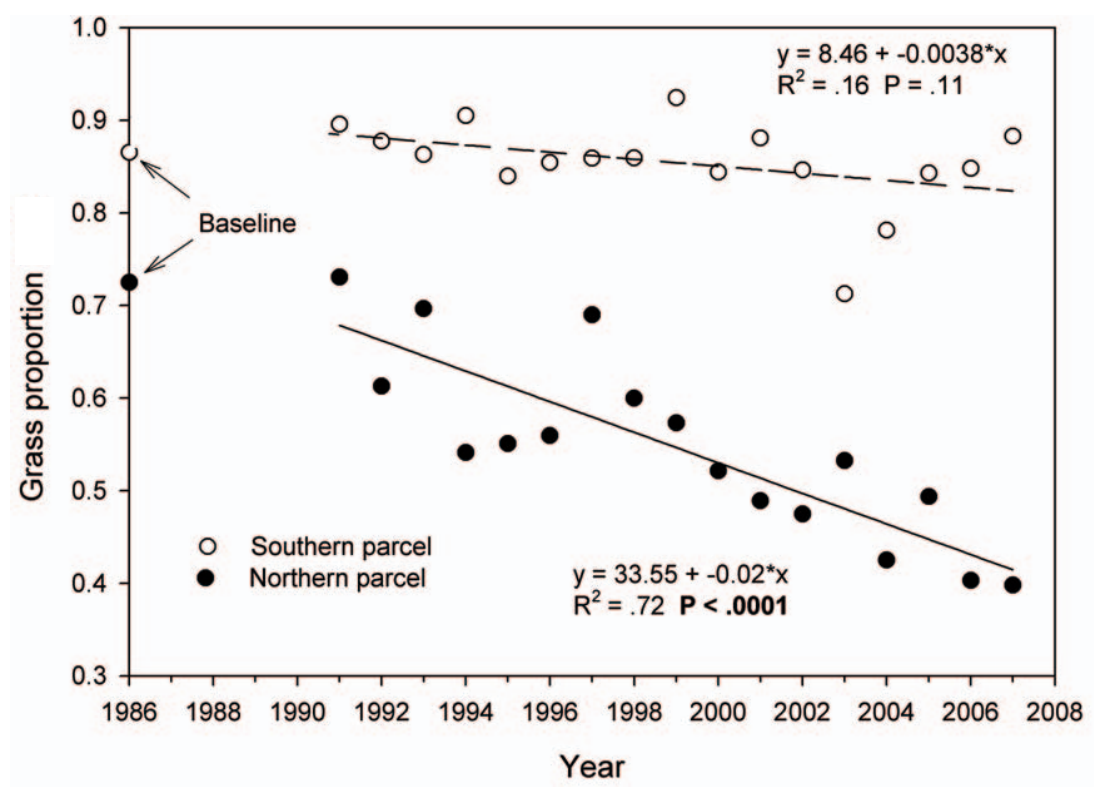

Fig. 3. Grass proportion from field monitoring data as a function of year (1991-2007) for the northern and southern study site meadows, Owens Valley, California.

field total cover, grass cover, and SMA cover with precipitation and with DTW in each meadow, 1991-2007 (1991-2006 for correlations involving SMA cover; Statsoft 2005). In addition to these individual meadow-based analyses of correlations, we pooled SMA cover data from both meadows to allow analysis of change in cover over the full range of DTW values in both meadows. We performed this analysis by means of ordinary least-squares regression (Systat 2006). The large range of DTW values made fitting data to a sigmoid curve more appropriate than fitting to a straight line (ter Braak 1996).

\section{Results}

\section{Cover Change}

In the northern meadow, annual means of field total cover were below baseline in every year except 1998 (Fig. 2). Mean field total cover and mean grass cover over the entire monitoring period (1991-2007) were $30.2 \%$ and $14.1 \%$, respectively. Both values were significantly below baseline values of $42.7 \%$ and $27.5 \%$, respectively $(P<0.01)$. Mean field shrub cover over the same 1991-2007 period in the northern meadow was $11.3 \%$, which did not differ significantly $(\alpha=0.05)$ from the baseline value of
$10.4 \%$. In the southern meadow, annual means of field total cover were at or above baseline in 11 of 17 years (Fig. 2). Mean field total cover, mean grass cover, and mean shrub cover, 19912007 , were $53.4 \%, 41.1 \%$, and $6.8 \%$, respectively. None of these values differed significantly $(\alpha=0.05)$ from their respective baseline values $(50.6 \%, 39.3 \%$, and $6.1 \%)$. The $1991-$ 2007 ranges of variation in annual mean field total cover were $42 \%$ and $41 \%$ for the northern and southern meadows, respectively (Fig. 2).

\section{Dominance-Type Conversion}

The meadows differed regarding trends in dominant life form. In the northern meadow, there was a significant negative trend in grass proportion over time $\left(\mathrm{R}^{2}=0.72, P<0.01\right)$. There was not a significant trend $(P=0.11)$ in the southern meadow (Fig. 3). Values of the Durbin-Watson statistic were 2.21 and 1.52, respectively, showing little evidence of serial correlation (Systat 2006).

\section{Cover-Water Relationships}

The meadows differed regarding cover response to water. In the northern meadow, SMA, field total, and grass cover were significantly positively correlated $(P<0.05)$ with precipitation (Spearman's $\mathrm{R}=0.66,0.63$, and 


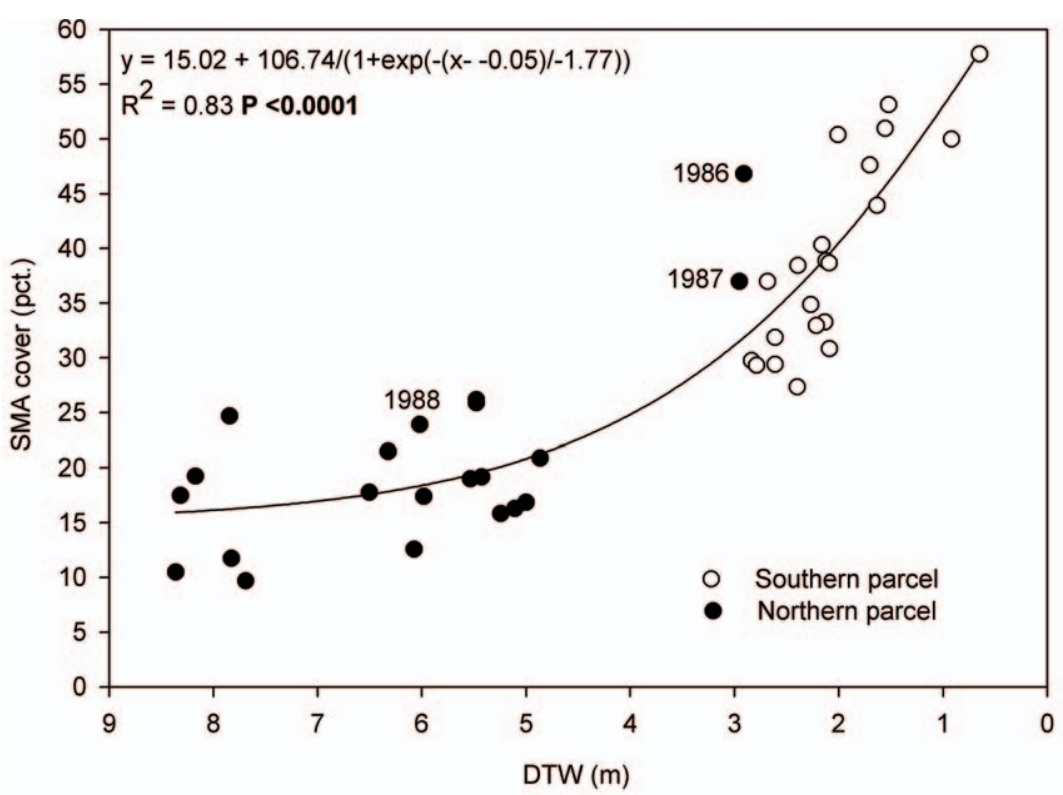

Fig. 4. Total photosynthetic vegetation cover as calculated by spectral mixture analysis (SMA) of Landsat data as a function of depth-to-water (1986-2006) in the northern and southern study site meadows, Owens Valley, California.

0.55 , respectively) but not with DTW. In the southern meadow, SMA, field total, and grass cover were significantly negatively correlated $(P<0.05)$ with DTW (Spearman's R $=-0.81$, -0.60 , and -0.50 , respectively) but not with precipitation. DTW explained $83 \%$ of the pooled SMA cover variation in both meadows over the entire 1986-2006 period (Fig. 4).

\section{Discussion}

Cover Change and Dominance-Type Conversion

The magnitudes of annual cover fluctuations in our data are not uncommon for Owens Valley well field meadows, as measured with the relatively small sample sizes of the Water Agreement monitoring protocol (Manning 2006). More important is that 1991-2007 cover values in the southern meadow fluctuated around the 1986 management baseline value, while cover values in the northern meadow fluctuated around a mean about $13 \%$ lower than baseline. This result is consistent with photographic evidence (Inyo County Water Department 2011). Observations of Stromberg et al. (1996), Elmore et al. (2003), and Cooper et al. (2006) also associate water table declines with cover decline. Especially relevant were predictions made in
1976 by the Los Angeles Department of Water and Power for its Owens Valley holdings, including the study site meadows. The department defined general classes of predicted responses to pumping-induced water table declines and associated them with 3 ranges of DTW values (Los Angeles Department of Water and Power 1976). The magnitude and duration of water table drawdowns in the northern meadow placed it in the "extreme" category of predicted responses. Phreatophytic species, "would definitely thin out and begin to die. Evidence of this change would be expected within three to five years, with definite marked changes in 10 years [after water table drawdowns]." The magnitude and duration of drawdowns under the southern meadow placed it in the "none-moderate-high" category of predicted responses. The fluctuations of mean field total cover and mean grass cover around baseline were consistent with this prediction.

The decline of grass proportion over time in the northern meadow (Fig. 3) indicated conversion from meadow to shrubland, but no similar trend was seen in the southern meadow. Groeneveld (1992) warned that management under the Water Agreement may accelerate meadow conversion to shrubland because deeprooted shrubs would be less vulnerable than 
grasses to water table declines and would also be able to respond more quickly than grasses when water tables begin to recover. The conversion from grass to shrub dominance in the northern meadow was also consistent with observations of Lee (1912), who mapped shrublands in areas with DTW deeper than $2.4 \mathrm{~m}(8$ $\mathrm{ft}$.) - a value he associated with the shrubland-meadow ecotone. Almost half the northern meadow had DTW >2.4 $\mathrm{m}$ in 1986 (Fig. 1). Instead of managing groundwater to return the $2.4 \mathrm{~m}$ DTW contour to its historic location at the northwest edge of the meadow, managers extracted groundwater (1986-2007) at rates which increased mean DTW under the entire northern meadow (and parts of the southern meadow) to levels exceeding $2.4 \mathrm{~m}$. Groeneveld and Or (1994) associated an Owens Valley meadow-shrubland ecotone with a DTW threshold of approximately $1 \mathrm{~m}$, even shallower than Lee's.

West and Young (2000) cited a model of succession around retreating (drying) Great Basin lakes in which succulent and graminoid species give way to shrublands along water and salinity gradients. In the northern meadow, grasses Distichlis spicata and Sporobolus airoides declined in cover relative to shrubs Atriplex lentiformis ssp. torreyi, Ericameria nauseosa, and Artemisia tridentata. These are all taxa in the succession model cited by West and Young (2000). The Los Angeles Department of Water and Power (1976) also predicted "plant succession shifts toward non-phreatophytes" and a "definite shift toward xerism" as a response to water table decline. Consistent with this prediction, the encroaching shrub species in the northern meadow were more xerophytic (lacking wetland indicator status values), than the grasses they replaced. Type conversion in the northern meadow can be understood as a pumping-induced acceleration of succession, which formerly occurred as a response to long-term climatic drying. Froend and Sommer (2010) described response of an Australian GDE to water table decline up to $50 \mathrm{~cm} \cdot$ year $^{-1}$ as a "transition to an alternative ecohydrological state." The northern meadow was subject to drawdowns up to $110 \mathrm{~cm}$. year $^{-1}$, and the resulting cover decline and type conversion makes "transition to an alternative ecohydrological state" an apt descriptor. Odion et al. (1992), Stromberg et al. (1996), Naumburg et al. (2005), Cooper et al. (2006), and Patten et al. (2008) all documented and/or predicted plant community change in response to long-term drawdowns.

\section{Cover-Water Relationships}

Although both study site meadows were classified as groundwater dependent under the Water Agreement on the basis of field data from 1986, the Spearman's R values demonstrate that the northern meadow was statistically precipitation dependent during 19912007, while the southern meadow remained groundwater dependent. The analysis of pooled data integrated the annual SMA cover and DTW values of both meadows in a single model (Fig. 4) showing the shape of the cover-DTW response curve over the full range of DTW values typically imposed on Owens Valley well field meadows (Manning 2006). The sigmoid curve describing this shape was also used by Shafroth et al. (2000) to describe the response of woody riparian vegetation to declining water table. The stem of the curve represents a range of relatively shallow DTW values where cover is correlated with changes in DTW. When DTW is in this range of values, groundwater is available to plant roots and overrides any effects of variation in precipitation on cover, as measured by methods used in this study. The tail of the sigmoid curve defines a range of DTW values where changes in DTW no longer affect cover because groundwater is too deep to be accessible to vegetation. In this range of values, effects of variation in precipitation on cover are measurable. Note that, under current climatic conditions, precipitation alone is not sufficient to sustain cover values as high as baseline values (City of Los Angeles and County of Inyo 1991b). As a result, when DTW is drawn down to the tail of the curve, it effectively limits cover, even as cover becomes correlated with precipitation.

Elmore et al. (2006) used SMA cover to identify $2.5 \mathrm{~m}$ as the mean threshold DTW value for meadow vegetation in Owens Valley above which there was measurable groundwater dependence and below which there was measurable precipitation dependence. Our results, using both field cover and SMA cover, are consistent with this threshold. Mean DTW under the northern meadow was close to the Elmore et al. (2006) range of groundwater dependence in 1986 and 1987, then mean DTW increased into the range of precipitation dependence for 
the duration of the study period (Fig 4). Cover responded accordingly as the meadow converted from groundwater to precipitation dependence. The response had been anticipated by the Los Angeles Department of Water and Power (1976), which predicted that vegetation "will move toward equilibrium with the desert environment and prevailing 5-inch rainfall potential" in areas subject to drawdowns of the magnitude and duration of those imposed on the northern meadow.

\section{Management Implications}

When the Water Agreement was adopted, the conceptual model it applied to management of Type III GDEs had not been tested (City of Los Angeles and County of Inyo 1991a). Our analysis of southern meadow monitoring data demonstrated that the Water Agreement conceptual model of exploiting ecosystem resilience could meet management goals with regard to total cover, grass dominance, and groundwater dependence over a 21-year period. Our analysis of northern meadow monitoring data, where water tables were drawn down well below the grass rooting zone continuously for 19 years, showed that this area was unable to sustain management baselines regarding cover, dominance type, and groundwater dependence. Our analysis of pooled data showed the overall importance $\left(\mathbf{R}^{2}=0.83\right)$ of groundwater in both sustaining and limiting cover (relative to baseline values) depending upon whether groundwater is in the rooting zone or drawn down below it.

Though management goals were met in the southern meadow, the applicability of the Water Agreement conceptual model elsewhere has important limitations. The mid-1986 baselines for the study site meadows represented disturbed conditions. They were set after the meadows had already been subjected to 14 years of relatively intensive pumping. Furthermore, baseline samples were small (Table 1) and not intended to fully document the diversity within each meadow (City of Los Angeles and County of Inyo 1991b). As a result, management success in the southern meadow was due, in part, to the coarse scale of management goals. We could not recommend application of the Water Agreement conceptual model to GDEs not already subject to impacts of hydrologic alteration.

An important unanswered question concerns the duration necessary for recovery after a deep drawdown such as that experienced in the northern meadow. The Los Angeles Department of Water and Power (1976) predicted "substantially longer periods [ $>10$ years] of normal conditions would be required for vegetation restoration." The Inyo County Water Department and the Los Angeles Department of Water and Power have been attempting since 2007 to reach agreement on optimum durations of cycles of drawdown and recovery but have yet to do so. Had the partial groundwater recovery of 1998 been allowed to continue to the grass rooting zone, data relevant to this question would have been obtained.

\section{Conclusion}

Given the increasing pressure to exploit groundwater resources in the arid lands of western North America (SNWA 2011) and globally (Postel 2000), it is important to recognize that Type III GDEs are vulnerable to groundwater withdrawals just as their more widely studied wetland and riparian GDE relatives. Long-term data regarding Type III GDEs had been lacking (Groeneveld 1992), but the data presented here help fill this void. Our results show the response of groundwater-dependent alkali meadow to water table declines of different magnitudes and duration. As seen in the southern meadow, short-term cycles of water table drawdown and recovery may avoid or at least defer measurable changes in cover and dominance type in the meadow ecosystem. Prolonged water table drawdown under the northern meadow resulted in conversion to an altered ecohydrological state-a response consistent with management predictions (Los Angeles Department of Water and Power 1976) but inconsistent with management objectives (City of Los Angeles and County of Inyo 1991a).

\section{ACKNOWLEDGMENTS}

We acknowledge the University of California White Mountain Research Station for use of the GIS lab to krig DTW data. Vegetation and DTW data are publicly available from the Inyo County Water Department. SMA analysis of Landsat data originated from a 1997 NASA Land Use/Land Cover Change Grant on which the second author was co-PI, with J. Mustard, J. Grant, and S. Hamburg of Brown University, and A. Steinwand of the Inyo County Water Department. 


\section{Literature Cited}

Baldwin, B., S. Boyd, B.J. Ertter, R.W. Patterson, T.J. Rosatti, and D.H. Wilken. 2002. The Jepson desert manual. University of California, Berkeley, CA.

BonHAM, C.D. 1989. Measurements for terrestrial vegetation. Wiley, New York, NY.

Boulton, A.J., And P.J. HanCOCK. 2006. Rivers as groundwater-dependent ecosystems: a review of degrees of dependency, riverine processes and management implications. Australian Journal of Botany 54: 133-144.

City of Los ANGELES AND CounTy of InYo. 1991a. Water from the Owens Valley to supply the second Los Angeles Aqueduct: 1970 to 1990, and 1990 onward, pursuant to a long term groundwater management plan, Final Environmental Impact Report. State Clearing House no. 89080705. [Cited August 2011]. Available from: http://www.inyowater.org/Water Resources/ 1991eir/default.htm

1991b. Green Book. [Cited August 2011]. Available from: http://www.inyowater.org/Water_Resources/ Greenbook.htm

Cooper, D.J., J.S. Sanderson, D.I. Stannard, and D.P. GroenEVELD. 2006. Effects of long term water table drawdown on evapotranspiration and vegetation in an arid region phreatophyte community. Journal of Hydrology 325:21-34.

CoufaL, G. 2001. Response to notice of dispute. In: LADWP response to McNally Canals Notice of Dispute. [Cited August 2011]. Available from: http://www.inyowater .org/McNallyDispute/DWP_Laws_Response_to_ Notice_of_Dispute.PDF

Eamus, D., R. Froend, R. Loomes, G. Hose, and B. MurRAY. 2006. A functional methodology for determining the groundwater regime needed to maintain the health of groundwater-dependent vegetation. Australian Journal of Botany 54:97-114.

Elmore, A.J., S.J. Manning, J.F. Mustard, and J.M. Craine. 2006. Decline in alkali meadow vegetation cover in California: the effects of groundwater extraction and drought. Journal of Applied Ecology 43:770-779.

Elmore, A.J., J.F. Mustard, and S.J. Manning. 2003. Regional patterns of plant community response to changes in water: Owens Valley, California. Ecological Applications 13:443-460.

Elmore, A.J., J.F. Mustard, S.J. Manning, and D.B. LoBELL. 2000. Quantifying vegetation change in semiarid environments: precision and accuracy of spectral mixture analysis and the normalized difference vegetation index. Remote Sensing of the Environment 73: 87-102.

ESRI. 2008. ArcGIS 9.3. ESRI Inc., Redlands, CA.

Froend, R., AND B. Sommer. 2010. Phreatophytic vegetation response to climatic and abstraction-induced groundwater drawdown: examples of long-term spatial and temporal variability in community response. Ecological Engineering 36:1191-1200.

Groeneveld, D. 1992. Owens Valley, California, plant ecology: effects from export groundwater pumping and measures to conserve the local environment. Pages 128-155 in C.A. Hall, V. Doyle-Jones, and B. Widawski, editors, The history of water: Eastern Sierra Nevada, Owens Valley, White-Inyo Mountains. White Mountain Research Station Symposium
Volume 4, Bishop, CA; [cited August 2011]. Available from: http://www.wmrs.edu/resources/reference\% 20documents/History\%20of\%20Water/wmrs4\%204$5 . p d f$

Groeneveld, D.P., AND D. OR. 1994. Water table induced shrub-herbaceous ecotone: hydrologic management implications. Water Resources Bulletin 30:911-920.

HaRRINGTON, R.F. 2003. Estimated depth-to-water beneath vegetation reinventory parcels, 1985-2003. Unpublished report, Inyo County Water Department, Independence, CA.

Harrington, R.F., and C. Howard. 2000. Depth to groundwater beneath vegetation reinventory parcels. Unpublished report. Inyo County Water Department, Independence, CA.

Hollett, K.J, W.R. Danskin, W.M. McCaffrey, and C.L. WALTI. 1991. Geology and water resources of Owens Valley, California. U.S. Geological Survey Water-Supply Paper 2370, U.S. Government Printing Office, Washington, DC.

Inyo County Water DePartment. 2011. Analysis of conditions in parcel Blackrock 94. Unpublished report, 2 February 2011. [cited August 2011]. Available from: www.inyowater.org/ICWD_Reports/Blackrock94_ 2009Analysis.pdf

LEE, C.H. 1912. An intensive study of the water resources of a part of Owens Valley, California. U.S. Geological Survey Water-Supply Paper 294, U.S. Government Printing Office, Washington, DC.

LEgENDRE, P., AND L. LEGENDRE. 1998. Numerical ecology. 2nd English edition. Elsevier Science, Amsterdam, The Netherlands.

Los Angeles Department of Water and Power. 1976. Final environmental impact report on increased pumping of the Owens Valley Groundwater Basin. Volume 1. May 1976.

2011. Los Angeles Department of Water and Power Annual Owens Valley Report, May 2011. [Cited August 2011]. Available from: http://www.ladwp.com/ladwp/ cms/ladwp014331.pdf

Manning, S.J. 2006. Status of re-inventoried vegetation parcels according to the Drought Recovery Policy, 2005. Unpublished report. Inyo County Water Department, Independence, CA; [cited August 2011]. Available from: http://www.inyowater.org/ICWD_Reports/ DRP_2005/DRP05.pdf

Naumburg, E., R. Mata-Gonzalez, R.G. Hunter, T. McLendon, And D.W. Martin. 2005. Phreatophytic vegetation and groundwater fluctuations: a review of current research and application of ecosystem response modeling with an emphasis on Great Basin vegetation. Environmental Management 35:726-740.

Odion, D.C., R.M. Callaway, W.R. Ferren JR., and FW. DAVIS. 1992. Vegetation of Fish Slough, an Owens Valley wetland ecosystem. Pages 171-197 in C.A. Hall, V. Doyle-Jones and B. Widawski, editors, The history of water: eastern Sierra Nevada, Owens Valley, WhiteInyo Mountains. White Mountain Research Station Symposium Volume 4, Bishop, CA; [cited August 2011]. Available from: http://www.wmrs.edu/resources/ reference $\% 20$ documents/History $\% 20 \mathrm{of} \% 20$ Water/ wmrs4\%204-7.pdf

Patten, D., L. Rouse, and J.C. Stromberg. 2008. Isolated spring wetlands in the Great Basin and Mojave deserts, USA: potential response of vegetation to groundwater withdrawal. Environmental Management 41:398-413. 
Postel, S.L. 2000. Entering an era of water scarcity: the challenges ahead. Ecological Applications 10:941-948.

Pritchett, D., And S.J. Manning. 2009. Effects of fire and groundwater extraction on alkali meadow habitat in Owens Valley, CA. Madroño 56:89-98.

Shafroth, P., J. Stromberg, and D. Patten. 2000. Woody riparian vegetation responses to different alluvial water table regimes. Western North American Naturalist 60:66-76.

[SNWA] Southern Nevada Water Authority. 2011. Clark, Lincoln, and White Pine Counties Groundwater Development Project; [cited August 2011]. Available from: http://www.snwa.com/ws/future_gdp.html

Stromberg, J.C., R. Tiller, and B. Richter. 1996. Effects of groundwater decline on riparian vegetation of semiarid regions: the San Pedro River, Arizona. Ecological Applications 6:113-131.

Statsoft. 2005. Stastica 7.1. Statsoft, Inc., Tulsa, OK

SYSTAT. 2006. SigmaPlot for Windows, version 10.0. Systat, Inc., Chicago, IL.

TER BRAAK, C.J.F. 1996. Unimodal models to relate species to environment. DLO-Agricultural Mathematics Group, Wageningen, The Netherlands.
[USEPA] United States Environmental Protection AgEnCY. 2011. Wetlands. [Cited August 2011]. Available from: http://waterepa.gov/type/wetlands/.

[USDA-NRCS] United States Department of AgRICULture-Natural Resources Conservation Service. 2002. Soil survey of Benton-Owens Valley and parts of Inyo and Mono Counties, CA. [Cited August 2011]. Available from: http://soildatamart.nrcs.usda.gov/ Manuscripts/CA802/0/Benton OwensValley CA.pdf

2011. The PLANTS Database. National Plant Data Team, Greensboro, NC; [cited August 2011]. Available from: http://plants.usda.gov

WEST, N.E., AND J.A. Young. 2000. Intermountain valleys, and lower mountain slopes. Pages 256-284 in M.G. Barbour and W.D. Billings, editors, North American terrestrial vegetation. 2nd edition. Cambridge University, New York, NY.

ZAR, J.H. 1984. Biostatistical analysis. 2nd edition. Prentice Hall, Englewood Cliffs, NJ.

Received 24 February 2011 Accepted 11 October 2011 